\title{
Yam: Is It a Functional Food?
}

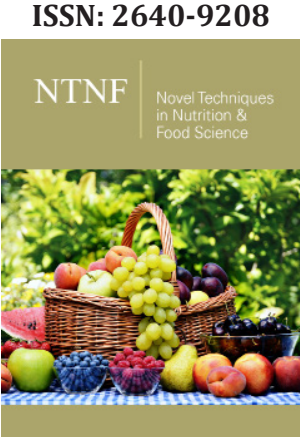

${ }^{* 1}$ Corresponding author: Monte Guedes CKR, Department of Nutrição, Brazil

Submission: 眥 July 01, 2019

Published: 眥 August 23, 2019

Volume 4 - Issue 2

How to cite this article: Monte G. Yam: Is It a Functional Food?. Nov Tech Nutri Food Sci. 4(2).NTNF.000585.2019.

DOI: 10.31031/NTNF.2019.04.000585

Copyright@ Monte Guedes, This article is distributed under the terms of the Creative Commons Attribution 4.0 International License, which permits unrestricted use and redistribution provided that the original author and source are credited.

\section{Monte Guedes CKR*}

Department of Nutrição, Brazil

\section{Opinion}

The yam (Dioscorea $s p$ ) belongs to the Discotic family and is a plant that has an herbaceous and scandal stem being characterized by forming tubers. The most broadcast are $D$ rotundata, $D$ alata, $D$ trífida, $D$ esculenta and $D$ cayennensis [1-3]. Its culture is quite common in African countries, especially in west Africa, but also in Brazil, mainly in Southeast and Northeast Regions [4-6]. The tuber is very well accepted in culinary, being used cooked itself or in preparations, but it's use is quite explored in other areas, such as the use for medicinal purposes, with promises to improve the systemic functioning of the organism and to be beneficial in the treatment of some diseases [7]. Because of the association the tuber has been studied for the purpose of maintenance and/or recovery health as well as their functional properties. The yam has important food characteristics. The analysis of its composition evidences that it's rich in carbohydrates, presenting a good energetic value, excellent fiber content, low glycemic index (37 \pm 8$)$ and glycemic load (13), being still a good source of vitamins and minerals (Table 1); [8-13]. Recent studies point to the beneficial effect and reinforce a diversity of properties related to tuber consumption, or its isolated bioactive compounds. The main functions attributed to the yam are immunomodulatory, antioxidant and anti-inflammatory action, modulation in lipid and glucose uptake and metabolism and performance as protective agent for the treatment and prevention of menopause, cancer and hypertension.

Table 1: Centesimal composition of yam (Dioscorea $s p$ ).

\begin{tabular}{|c|c|c|c|c|c|c|c|c|}
\hline Species & Author & $\begin{array}{c}\text { Moisture } \\
(\mathbf{6})\end{array}$ & $\begin{array}{c}\text { Energy } \\
(\mathbf{K c a l} / \mathbf{K})\end{array}$ & $\begin{array}{c}\text { Protein } \\
\mathbf{( g )}\end{array}$ & $\begin{array}{c}\text { Lipid } \\
\mathbf{( g )}\end{array}$ & $\begin{array}{c}\text { Carbohy- } \\
\text { drate (g) }\end{array}$ & $\begin{array}{c}\text { Fiber } \\
\text { (g) }\end{array}$ & $\begin{array}{c}\text { Ash } \\
\text { (g) }\end{array}$ \\
\hline $\begin{array}{c}\text { Dioscorea } \\
\text { sp }\end{array}$ & 10 & 65.62 & $\begin{array}{c}137.98 / \\
576.76\end{array}$ & 3.06 & 0.86 & 29.5 & - & 0,96 \\
\hline D alata L & 11 & 73.7 & $\begin{array}{c}96.00 / \\
400.00\end{array}$ & 2.3 & NA & 23 & 7.3 & 0.9 \\
\hline D alata & 12 & 76.8 & $\begin{array}{c}105.56 \mathrm{~b} / \\
441.24\end{array}$ & 1.77 & 0.08 & 24.44 & 0.75 & 0.86 \\
\hline $\begin{array}{c}\text { D Cayen- } \\
\text { nensis }\end{array}$ & 13 & 81.47 & $\begin{array}{c}73.33 / \\
306.52\end{array}$ & 0.77 & 0.17 & 17.18 & 2.24 & 0.42 \\
\hline
\end{tabular}

${ }^{a}$ Converted to wet basis.

${ }^{\mathrm{b}}$ Calculated based on protein, lipid and carbohydrate values.

NA: Not applicable.

There are several components involved in the realization of these functions, such as Dioscuri, the major tuber storage protein of yam and one of the most studded one and well related to antioxidant effect associated to improve the immunologic system [14,15]. The antioxidant effect is also pointed to the flavonoids present in the tuber; evidences show that it is involved in modulation of lipid peroxidation [16].

Other studies cited the discerning, related specially to immunomodulatory effect, being tested with excellent results as anti-viral [17]. The modulation of lipid and glucose metabolism is commonly associated to allantois or the use of extract or the yam itself, presented an ant obesogenic effect too $[18,19]$. The protective effect against cancer, especially the breast and colon are further studied with the use of yam extract or a culinary preparation with yam 
$[20,21]$. The hypertension is also prevented in use of in nature yam or Dioscuri isolated, by inhibitory effect on angiotensin-converting enzyme (ACE) activity [22,23]. The yam is classically used in natural hormone replacement in the fight against menopause. Pieces of evidence pointed that estrogenic action apparently is associated to the consumption of the whole food and not of specific compounds [24]. Taking in account that functional foods are foods that have a potentially positive effect on health beyond basic nutrition and that the yam presents a diversity of factors that fit it as such. I'm secure, based in whole of these evidences pointed, that the yam as a functional food. In addition to the basic nutritional characteristics, the tuber exerts a positive effect on health and disease prevention.

\section{References}

1. Tunger L (1975) J.W. Purseglove: Tropical Crops. Monocotyledons band 1 und 2, 1. Aufl. 1972, zusammen 607 Seiten und 32 Abb., Leinen, Preis: 11,00£ Tropical Crops, Dicotyledons, 3. Aufl. 1974, 702 Seiten, 102 Abb., kartoniert, Preis: 4,95£. Verlag Longman Limited, Beccles, Colcher. Food/Nahrung 19(5-6): 519-519.

2. FAO. Dioscorea cayennensis. Ecocrop.

3. USDA (1789) Taxon: Dioscorea cayennensis Lam. U.S. National Plant Germplasm System.

4. Asiedu R, Sartie A (2010) Crops that feed the World 1. Yams. Food security 2(4):305-315.

5. FAO (2013) Faostat.

6. Brazil. Agricultural Census (2006) Brazil, major regions and federation units. Brazilian Institute of Geography and Statistics.

7. LI S, Mu TSK (1956) Nanjing, China.

8. Powell KF, Holt SH, Miller JCB (2002) International table of glycemic index and glycemic load values: 2002. Am J Clin Nutr 76(1): 5-56.

9. Brazil (2010) Ministry of Agriculture, Livestock and Supply.

10. Brito TT, Soares LS, Furtado MC, Castro AA, Carnelossi MAG (2011) Composição centesimal de inhame (Dioscorea sp) in natura e minimamente processado. Scientia Plena 7(6): 1-7.

11. UNICAMP (2011) Tabela Brasileira de Composição de Alimentos. Núcleo de Estudos e Pesquisas em Alimentação (NEPA)

12. Paula, Pirozi MCD, Puiatti M, Borges JT, Durango AM (2012) Physicochemical and morphological characteristics of rhizophores of inhame (Dioscorea alata). Biotechnol in the Agropecu and Agroindustrial Sect 10(2): 61-70.
13. Guedes CKRM (2014) Technological potential of yam (Discorea cayennensis) in the formulation of functional drinks based on tropical fruits and Lactobacillus casei.

14. Han CH, Liu JC, Fang SU, Hou WC (2013) Antioxidant activities of the synthesized thiol-contained peptides derived from computer-aided pepsin hydrolysis of yam tuber storage protein, dioscorin. Food Chem 138(2-3): 923-930.

15. Hsu JY, Chu JJ, Chou MC, Chen YW (2013) Dioscorin pre-treatment protects A549 human airway epithelial cells from hydrogen peroxideinduced oxidative stress. Inflammation 36(5): 1013-1019.

16. Jayachandran KS, Vasanthi HR, Rajamanickama GV (2010) Flavonoid rich fraction of Dioscorea bulbifera Linn (Yam) enhances mitochondrial enzymes and antioxidant status and thereby protects heart from isoproterenol induced myocardial infarction. Curr Pharm Biotechnol 11(8): 887-894.

17. Liu C, Wang Y, Wu C, Pei R, Song J, et al. (2013) Dioscin's antiviral effect in vitro. Virus Res 172(1-2): 9-14

18. Chen MF, Yang TT, Yeh LR, Chung HH, Wen YJ, et al. (2012) Activation of imidazoline $\mathrm{i}-2 \mathrm{~b}$ receptors by allantoin to increase glucose uptake into $\mathrm{C}_{2} \mathrm{C}_{12}$ cells. Horm Metab Res 44(4): 268-272.

19. HW G, EY L, JH L, Kim YS, Lee BE, et al. (2015) Dioscorea batatas extract attenuates high-fat diet-induced obesity in mice by decreasing expression of inflammatory cytokines. Med Sci Monit 21: 489-495.

20. Mazzio E, Badisa R, Mack N, Deiab S, Soliman KFA (2014) High throughput screening of natural products for anti-mitotic effects in mdamb-231 human breast carcinoma cells. Phytother Res 28(6): 856-867.

21. Miyoshi N, Nagasawa T, Mabuchi R, Yasui Y, Wakabayashi K, et al. (2011) Chemoprevention of azoxymethane/dextran sodium sulfate-induced mouse colon carcinogenesis by freeze-dried yam sanyaku and its constituent diosgenin. Cancer Prev Res 4(6): 924-934.

22. Hsu FL, Lin YH, Lee MH, Lin CL, Hou WC (2002) Both Dioscuri, the tuber storage protein of yam (Dioscorea alata, Tainong No. 1), and its peptic hydrolysates exhibited angiotensin converting enzyme inhibitory activities. J Agric Food Chem 50(21): 6109-6113.

23. Liu YH, Lin YS, Liu DZ, Han CH, Chen CT, et al. (2009) Effects of different types of yam (Dioscorea alata) products on the blood pressure of spontaneously hypertensive rats. Biosci Biotechnol Biochem 73(6): 1371-1376.

24. Hsu KH, Chang CC, Tsai HD, Tsai FJ, Hsieh YY (2008) Effects of yam and diosgenin on calpain systems in skeletal muscle of ovariectomized rats. Taiwan J Obstet Gynecol 47(2): 180-186. 